\title{
Kualitas Karya Tulis Ilmiah Mahasiswa: Hubungan Persepsi dan Karakteristik Dosen Pembimbing
}

\author{
Regina Satya Wiraharja, Felicia Kurniawan \\ Departemen IImu Kesehatan Masyarakat Fakultas Kedokteran Universitas Atma Jaya Jakarta
}

\begin{abstract}
Background: Since 2006 evaluation of scientific writing process, as graduation requirement in Faculty of Medicine Atma Jaya Catholic University, has not been done.

Objective: To find out supervisors perceptions on quality of under graduate theses and its relationship to supervisers' charactristics.

Metbod: This descriptive study was done to 29 supervisors. Interviewes were done using questionnaire. Dependent variable was perceptions on quality of under graduate theses (idea, proposal, writing process, presentation and publication). Independent variables were characteristic, knowledge, attitude and behavior of supervisors related to process of scientific writing. Data was analysed using chi square test.

Result: There was equal proportion (50\% vs 50\%) between good perception and bad perception on quality of undergraduate theses. Significant relationship was found between perception on quality with supervisors attitude $(p=0.04)$ and master degree ( $p=0.02)$. Supervisors aged 45 years old and less (53\% vs $47 \%)$, bave taught for 10 years and less $(64 \%$ vs 39\%), have academic position as assistant and lectur (5\% vs 47\%), have published articles within the last 3 years (40 $\%$ vs 60\%), have more than one research within the last 3 years (56\% vs $4 \%$ ), have non positive attitude (78\% vs 27\%), supervise students twice or more (57\% vs 43\%), meet student for less than 45 minutes per meeting (67\% vs 33\%), were more like to perceive low quality of under graduate theses.

Conclusion: Supervisors generally perceive that qualities of under graduate theses are still low. Positive attitude and non-magister supervisors tend to perceive the quality of theses to be good.
\end{abstract}

Keywords: Under Graduate Theses, Supervisors, Perspective

\section{ABSTRAK}

Latar Belakang: Sejak tahun 2006 evaluasi terhadap kegiatan karya tulis ilmiah di Fakultas Kedokteran Universitas Katolik Atma Jaya belum pernah dilakukan.

Tujuan: Mengetahui persepsi dosen pembimbing terhadap kualitas KTI mahasiswa dan hubungannya dengan karakteristik dosen pembimbing.

Metode: Penelitian deskriptif dilakukan terhadap 29 dosen pembimbing. Wawancara dilakukan dengan kuesioner. Variabel tergantung meliputi persepsi mengenai kualitas KTI (ide, proposal, penulisan, ujian presentasi, publikasi). Variabel bebas meliputi karakteristik, pengetahuan, sikap dan perilaku dosen pembimbing. Analisis yang digunakan adalah uji chi square.

Hasil: Masing-masing ada 50\% dosen yang memberikan pendapat baik dan buruk tentang kualitas karya tulis mahasiswa. Terdapat hubungan yang bermakna untuk sikap dosen $(\mathrm{p}=0,04)$ dan pendidikan magister $(\mathrm{p}=0,02)$. Dosen yang berumur kurang dari 45 tahun (53\% vs 47\%), mengajar 10 tahun ke bawah $(64 \%$ vs 34\%), berjabatan akademik asisten ahli dan lektor (53\% vs $47 \%$ ), berpendidikan magister (69\% vs $31 \%$ ), mempunyai publikasi dalam 3 tahun terakhir (40\% vs $60 \%)$, melakukan penelitian lebih dari 1 dalam 3 tahun terakhir (56\% vs $44 \%$ ), bersikap tidak positif (78\% vs $27 \%)$, membimbing 2 kali atau lebih (57\% vs 43\%), lama bimbingan kurang dari 45 menit (67\% vs 33\%), lebih banyak menyatakan bahwa kualitas KTI yang mereka bimbing masih rendah. Kesimpulan: secara umum persepsi dosen terhadap kualitas KTI masih rendah. Sikap dosen yang pasif terhadap KTI dan pendidikan non magister cenderung memiliki persepsi KTI yang dibimbing sudah baik.

Kata Kunci: Karya Tulis Ilmiah, Perspektif, Dosen Pembimbing

Korespondensi: reginasatya@yahoo.com 


\section{PENDAHULUAN}

Karya Tulis Ilmiah (KTI) merupakan sebuah karya yang ditulis dengan metode ilmiah dan dipublikasikan untuk menggambarkan suatu hasil penelitian atau pemikiran yang orisinil. Para peneliti menggunakan metode ilmiah untuk mencari hubungan antara penyebab dan dampak dari suatu fenomena ${ }^{1}$.

Fakultas Kedokteran Universitas Katolik Atma Jaya (FKUAJ) sejak tahun 2006 menerapkan penulisan KTI sebagai salah satu syarat kelulusan Sarjana Kedokteran. KTI dipilih sebagai salah satu syarat kelulusan Sarjana Kedokteran karena kemampuan mengaplikasikan metode ilmiah dan menulis sangat penting bagi mahasiswa. Kumar et al menemukan bahwa 70\% mahasiwa menganggap penelitian dan penulisan ilmiah adalah penting ${ }^{2}$. Selain itu, kemampuan menulis juga berguna untuk mengembangkan pola pikir mahasiswa dalam mengembangkan metode ilmiah, mencari topik penelitian dan berlatih untuk fokus terhadap topik penelitian yang sudah ada.-5

Evaluasi terhadap proses pembuatan dan penulisan KTI belum pernah dilakukan di FKUAJ. Menurut penelitian yaitu; 10\% mahasiswa merasa kemampuan menulis mereka masih kurang, dan ada $30 \%$ dosen yang menilai kemampuan menulis mahasiswa kurang. ${ }^{2}$ Sampai tahun 2010, terdapat sekitar 250 KTI yang sudah selesai. Oleh karena itu terlepas dari nilai yang diberikan oleh dosen pembimbing dan penguji, peneliti ingin melakukan studi mengenai persepsi dosen pembimbing terhadap kualitas KTI yang dibuat mahasiswa dan hubungannya dengan karakteristik dosen pembimbing di FKUAJ.

\section{METODE}

Penelitian ini merupakan penelitian deskriptif yang dilaksanakan sejak Januari sampai dengan Desember 2011. Populasi penelitian adalah seluruh dosen pembimbing KTI mahasiswa di FKUAJ. Populasi terjangkau adalah dosen pembimbing angkatan 2006 sampai dengan 2008 di FKUAJ, karena KTI pada ketiga angkatan ini sebagian besar telah selesai. Dosen pembimbing yang diikutsertakan dalam penelitian ini adalah dosen pembimbing yang aktif mengajar pada saat penelitian dilakukan, dan pernah membimbing minimal 3 karya tulis dengan minimal satu penelitian. Dosen yang menolak untuk ikut serta dalam penelitian atau yang tidak berhasil ditemui setelah dilakukan tiga kali perjanjian, tidak diikut sertakan dalam penelitian ini.

Data diambil dengan wawancara menggunakan kuesioner kualitatif dan kuantitatif. Kuesioner disusun berdasarkan beberapa literatur. Penelitian Nieminen 2007 menggunakan kuesioner yang pertanyaannya meliputi organisasi karya tulis, kualitas teknis, kesalahan penulisan, presentasi tabel dan gambar dan penulisan literature. ${ }^{8}$ Penelitian Reynolds menggunakan BioTap, yaitu panduan untuk penulisan karya tulis ilmiah. ${ }^{9}$ Panduan ini dapat juga digunakan dalam evaluasi karya tulis ilmiah. BioTap membagi kualitas karya tulis dalam 5 dapat yaitu isu utama (kesesuaian dengan target pengguna karya tulis yang diharapkan bersifat luas, argumentasi sesuai literatur terkini, kesesuaian dengan tujuan, intepretasi hasil, penjelasan terhadap hal-hal yang tidak jelas/tidak bermakna dan keterbatasan penelitian, diskusi mengenai kemungkinan pemecahan masalah di masa depan), aspek tambahan (organisasi karya tulis, kesalahan penulisan, literatur yang digunakan, kejelasan presentasi tabel dan gambar). Masing-masing aspek ini dinilai dengan skala yang terbagi 3 yaitu tidak dapat diterima (bobot nol), diterima (bobot 2) dan sangat baik (bobot 4). ${ }^{13}$ Kualitas akhir dinilai dari nilai totalnya. Selain dua penelitian tersebut, kuesioner juga disusun berdasarkan poin-poin penting dalam buku Pedoman Prosedur Penyusunan Karya Tulis Ilmiah FKUAJ tahun 2007. Uji coba kuesioner dilakukan pada lima orang dosen pembimbing KTI yang tidak termasuk dalam daftar responden. Uji coba kuesioner ini dilakukan untuk mendapatkan perkiraan waktu yang dibutuhkan untuk wawancara, perkiraan mengenai apakah kata-kata dalam pertanyaan sudah cukup jelas, perkiraan mengenai jawaban-jawaban dari pertanyaan terbuka dan tertutup. Selain itu untuk memperkirakan perlu tidaknya penambahan atau pengurangan pertanyaan pada kuesioner.

Sebelum wawancara dimulai, pewawancara menjelaskan maksud dan tujuan dari penelitian ini dan meminta persetujuan melalui informed consent. Variabel tergantung pada penelitian ini meliputi persepsi dosen mengenai kualitas dalam pencarian dan pengembangan ide, kualitas pembuatan proposal dan penulisan KTI, kualitas dalam ujian presentasi KTI dan kualitas dalam publikasi KTI (dengan nilai 1 untuk kurang, nilai 2 untuk cukup dan nilai 3 untuk baik). Skor untuk masing-masing poin dijumlahkan dan dihitung rata-ratanya untuk kemudian 
digunakan sebagai nilai batas penilaian kualitas secara umum. Variabel bebas dalam penelitian ini meliputi karakteristik dosen (umur, departemen, jabatan akademik, lama mengajar, pendidikan magister, pengalaman penelitian dan publikasi yang telah dilakukan), pengetahuan dosen pembimbing (peruntukan buku pedoman KTI, tugas dosen, jumlah bimbingan minimal, jenis KTI, bagian KTI, kriteria penilaian ujian KTI, lamanya sumber pustaka sesuai dengan pedoman KTI FKUAJ), sikap dosen pembimbing (sikap dosen terhadap tugas dosen pembimbing dan kriteria penilaian untuk ujian KTI serta lamanya sumber pustaka diukur dengan skala likert yang sudah disederhanakan menjadi setuju, ragu-ragu/tidak tahu dan tidak setuju). Perilaku dosen pembimbing (kepemilikan dan dibaca tidaknya buku pedoman prosedur penyusunan KTI, praktek bimbingan, partisipasi dosen dalam proses penelitian dan pencarian literatur, partisipasi dosen dalam mengoreksi KTI, banyaknya bimbingan, lama rata-rata setiap kali bimbingan).

Jawaban untuk pengetahuan dan sikap diberikan skor 1 bila benar dan 0 bila salah/tidak tahu, sehingga total skor untuk pengetahuan adalah 64 dan untuk sikap adalah 17. Pengetahuan dan sikap kemudian dikategorikan menurut rata-rata skor. Persepsi dosen mengenai kualitas KTI dilakukan dengan memberikan skor 3 untuk kategori baik, 2 untuk kategori cukup, dan 1 untuk kategori kurang pada tiap pertanyaan dalam kuesioner, dengan total nilai terendah 14 dan tertinggi 42. Data kemudian dikategorisasikan menjadi tinggi dan rendah dengan median dari jumlah skor dipakai sebagai nilai batas. Data diolah dengan SPSS 15 secara deskriptif maupun dengan uji chi square.

\section{HASIL DAN PEMBAHASAN}

\section{Jumlah dan Karakteristik Responden}

Berdasarkan data yang didapatkan dari tata usaha FKUAJ, ada 35 dosen yang memenuhi kriteria inklusi. Pada akhir penelitian, ada enam orang (17,2 \%) yang tidak dapat diikutsertakan dalam penelitian ini karena menolak (5 orang) atau tidak dapat ditemui setelah tiga kali perjanjian (1 orang) sehingga jumlah seluruh responden ada 29 orang.

Tabel 1 menunjukkan bahwa sebagian besar dosen berumur 30-45 tahun (51,7\%), mengajar kurang dari 10 tahun atau lebih dari 20 tahun (37,9\%), merupakan dosen bagian non klinik (51\%), lektor kepala dan guru besar $(44,8 \%)$ dan bergelar magister (55\%).

Tabel 1. Distribusi karakteristik dosen pembimbing

\begin{tabular}{|c|c|c|}
\hline \multirow{2}{*}{\multicolumn{3}{|c|}{ Karakteristik }} \\
\hline & & \\
\hline $30-45$ tahun & 15 & 51,7 \\
\hline $46-60$ tahun & 4 & 13,8 \\
\hline $61-75$ tahun & 10 & 34,5 \\
\hline \multicolumn{3}{|l|}{ Lama Mengajar } \\
\hline $1-10$ tahun & 11 & 37,9 \\
\hline $11-20$ tahun & 7 & 24,1 \\
\hline$>20$ tahun & 11 & 37,9 \\
\hline \multicolumn{3}{|c|}{ Departemen Dosen Mengajar } \\
\hline Klinik & 14 & 48,3 \\
\hline Non-klinik & 15 & 51,7 \\
\hline \multicolumn{3}{|l|}{ Jabatan Akademik } \\
\hline Asisten Ahli & 10 & 34,5 \\
\hline Lektor & 6 & 20,7 \\
\hline $\begin{array}{l}\text { Lektor Kepala dan Guru } \\
\text { Besar* }^{*}\end{array}$ & 13 & 44,8 \\
\hline \multicolumn{3}{|l|}{ Gelar } \\
\hline Magister & 16 & 55,2 \\
\hline Bukan magister (spesialis) & 13 & 44,8 \\
\hline
\end{tabular}

* Hanya 1 dosen yang berjabatan akademik guru besar 
Tabel 2 menunjukkan bahwa sebagian besar dosen melakukan lebih dari 2 penelitian dalam tiga tahun terakhir $(41,4 \%)$ dan tidak mempunya publikasi dalam tiga tahun terakhir $(44,8 \%)$.

Tabel 2. Distribusi dosen pembimbing menurut pengalaman penelitian dan publikasi

\begin{tabular}{lcc}
\hline Pengalaman penelitian dan publikasi & $\mathbf{n}=\mathbf{2 9}$ & $\%$ \\
\hline Banyaknya Penelitian dalam Tiga Tahun Terakhir* & & \\
0 & 7 & 24,1 \\
$1-2$ & 10 & 34,5 \\
$>2$ & 12 & 41,4 \\
Posisi Dosen dalam Penelitian & $\mathbf{n}=22$ & $\%$ \\
Peneliti utama & 6 & 27,3 \\
Peneliti pendamping & 5 & 22,7 \\
Peneliti tunggal & 11 & 50,0 \\
Banyaknya Publikasi ke Majalah Ilmiah Nasional dalam Tiga Tahun Terakhir ${ }^{* *}$ & $\mathbf{n}=\mathbf{2 9}$ & $\%$ \\
0 & 13 & 44,8 \\
1 & 7 & 24,1 \\
Lebih dari 1 & 9 & 31,0 \\
Posisi Dosen dalam Publikasi Nasional & $\mathbf{n}=16$ & $\%$ \\
Penulis utama & 11 & 68,9 \\
Penulis kedua & 3 & 18,8 \\
Penulis utama dan kedua & 2 & 12,5 \\
Banyak Publikasi ke Internasional dalam Tiga Tahun Terakhir & $\mathbf{n = 2 9}$ & $\%$ \\
0 & 27 & 93,1 \\
1 & 2 & 6,9 \\
Posisi Dosen dalam Publikasi Internasional & $\mathbf{n = 2}$ & $\%$ \\
Penulis utama & 2 & 100 \\
\hline
\end{tabular}

*Mean=2,59; Median=20; Modus=0; Minimum=0; Maksimum=10

**Mean=1,55; Median=1,0; Modus=0; Minimum=0; Maksimum=12

\section{Pengetahuan Dosen Pembimbing}

Tabel 3 menunjukkan bahwa sebagian besar dosen memiliki pengetahuan di atas rata-rata $(55,2 \%)$, sedangkan nilai rata-ratanya sendiri cukup tinggi yaitu 57 dari skor total 64 . Nilai minimum yang didapatkan juga cukup tinggi yaitu 50 dari skor total 64 .

Tabel 3. Distribusi dosen pembimbing menurut kategori pengetahuan

\begin{tabular}{ccc}
\hline Pengetahuan * & $\mathbf{n}=\mathbf{2 9}$ & $\%$ \\
\hline Di atas rata-rata & 16 & 55,2 \\
Di bawah rata-rata * & 13 & 44,8 \\
\hline
\end{tabular}

${ }^{*}$ Mean $=57 ;$ Median $=58 ;$ Modus=50; Maksimum $=64$; Minimum $=50$

** Di atas rata-rata untuk skor $>57$; dibawah rata-rata untuk skor $\leq 57$
Beberapa pernyataan yang dijawab salah oleh para dosen pembimbing adalah topik studi kepustakaan merupakan topik yang sering dibahas $(48,3 \%)$, pendahuluan merupakan bagian pembuka dari KTI (37,5\%), review artikel merupakan salah satu jenis KTI $(34,5 \%)$, hipotesis merupakan bagian dari abstrak (34,5\%), penilaian dalam ujian presentasi KTI meliputi nada bicara mahasiswa $(24,1 \%)$, kelancaran bicara $(30,1 \%)$ dan keindahan presentasi $(20,7 \%)$, menjawab salah mengenai isi bab tiga dan empat dari KTI penelitian (27,6\% dan 24,1\%), menjawab salah mengenai jangka waktu sumber informasi yang sebaiknya digunakan $(25,1 \%)$, studi kasus merupakan salah satu jenis KTI $(24,1 \%)$, studi kepustakaan merupakan sharing dari penemuan non ilmiah (24,1\%), dosen pembimbing ikut campur dalam pelaksanaan penelitian mahasiswa $(20,7 \%)$, daftar isi 
dan kata pengantar bukan merupakan bagian pembuka dari KTI $(20,7 \%)$

\section{Sikap Dosen Pembimbing}

Sebagian besar dosen pembimbing memiliki sikap yang positif (69\%), yang ditandai dengan nilai rata-rata 15 dan nilai minimum 13, dari skor total 17 (tabel 4).

Tabel 4. Distribusi dosen pembimbing menurut kategori sikap

\begin{tabular}{ccc}
\hline Sikap * & $\mathbf{n}=29$ & $\%$ \\
\hline Positif** & 20 & 69,0 \\
Tidak positif & 9 & 31,0 \\
\hline
\end{tabular}

* Mean $=15 ;$ Median=15; Modus=15;

Maksimum=17; Minimum=13

** Sikap positif untuk skor $\geq 15$; sikap tidak positif untuk skor $<15$

Penelitian ini menemukan bahwa 31\% dosen setuju untuk ikut campur dalam pelaksanaan penelitian mahasiswa, namun menurut buku bedoman KTI FKUAJ seharusnya dosen pembimbing hanya melakukan pengawasan pada penelitian mahasiswa. Selain itu, ada 24,1\% dosen yang setuju untuk ikut mencarikan literatur dan ada $24,1 \%$ dosen yang setuju untuk mengoreksi kesalahan-kesalahan yang penting saja. Hal ini tidak sesuai dengan pedoman KTI FKUAJ karena seharusnya dosen hanya memberi petunjuk dalam pencarian literatur dan mengoreksi seluruh kesalahan yang ada. ${ }^{6}$ Dalam ujian KTI, 31\% dosen setuju bahwa sistematika proposal tidak dinilai. Hal ini tidak tepat karena pada saat ujian presentasi, selain penyajian lisan, tanya jawab dan sikap, sistematika proposal pun dinilai. ${ }^{6}$ (lampiran 1).

\section{Perilaku Dosen Pembimbing}

Seluruh dosen pembimbing telah memiliki pedoman prosedur penyusunan KTI dan hanya 2 orang (7\%) yang belum pernah membacanya. Dosen pembimbing yang tidak membantu mahasiswa dalam memilih topik $(34,5 \%)$, tidak membantu mahasiswa dalam mengembangkan kerangka teori dan konsep (34,5\%) atau tidak membantu mahasiswa dalam memilih metode analisis (41,4\%). Sebagian besar dosen pembimbing hanya memberikan petunjuk dalam pencarian literatur (65,5\%), sedangkan sisanya membantu mencarikan literatur (44,8\%), misalnya dengan memberikan literatur miliknya atau mencarikan salah satu literatur lengkap. Tidak ada dosen yang tidak membantu dalam pencarian literatur.

Sebagian besar juga berpartisipasi dalam proses penelitian seperti ikut mengawasi jalannya penelitian mahasiswa (65\%). Partisipasi lain yang dilakukan dosen selama proses penelitian adalah mengadakan seminar kecil untuk mengetahui manfaat penelitian, melibatkan mahasiswa dalam penelitian departemen, membantu mahasiswa dalam analisis, membantu memecahkan masalah yang timbul pada saat penelitian, melakukan diskusi untuk membahas hal-hal yang kurang tepat dan dilakukan perbaikan, hanya memberi saran dan membantu mencarikan penelitian untuk kasus tertentu (masing-masing dijawab oleh 1 dosen yang berbeda). Hanya 31\% dosen pembimbing yang tidak ikut dalam pelaksanaan penelitian mahasiswa.

Dosen pembimbing sebagian besar mengoreksi seluruh kesalahan $72,4 \%$ dan $27,6 \%$ dosen mengoreksi kesalahan penting. Beberapa hal yang dikoreksi oleh dosen adalah tata bahasa, format penulisan KTI dan alternatif untuk pemecahan masalah yang dihadapi mahasiswa. 
Tabel 5. Distribusi dosen menurut perilaku membimbing KTI mahasiswa

\begin{tabular}{lcc}
\multicolumn{1}{c}{ Perilaku } & $\mathbf{n}$ (n=29) & \% \\
\hline Memiliki pedoman prosedur penyusunan KTI & 29 & 100,0 \\
Pernah membaca pedoman KTI. & 27 & 93,1 \\
Membantu mahasiswa memilih topik sesuai minat mahasiswa & 19 & 65,5 \\
Membantu mahasiswa mengembangkan kerangka teori dan konsep & 19 & 65,5 \\
Membantu mahasiswa melihat alternatif metode analisis & 17 & 58,6 \\
Membantu mahasiswa dengan mencarikan literatur & 13 & 44,8 \\
Hanya memberi petunjuk untuk mencari literatur & 19 & 65,5 \\
Tidak ikut campur sama sekali dalam pencarian literature & 0 & 0 \\
Ikut campur tangan dalam penelitian & 10 & 34,5 \\
Hanya melakukan pengawasan pelaksanaan penelitian & 19 & 65,5 \\
Tidak ikut campur tangan dalam penelitian & 9 & 31,0 \\
Mengoreksi seluruh kesalahan yang ada & 21 & 72,4 \\
Mengoreksi kesalahan yang penting saja & 8 & 27,6 \\
Jumlah bimbingan dalam satu bulan 1 -2 kali & 17 & 58,6 \\
Jumlah bimbingan dalam satu bulan lebih dari 2 kali & 12 & 41,4 \\
Lama tiap kali bimbingan kurang dari 45 menit & 10 & 34,5 \\
Lama tiap kali bimbingan 45 menit atau lebih & 19 & 65,5 \\
\hline
\end{tabular}

* Mean=2,64; Median=2,0; Modus=2; Minimum=1; Maksimum=6

**Mean=47,4; Median=45,0; Modus=60; Minimum=15 pada 2 responden (7\%);

Maksimum=90 pada 2 responden $(7 \%)$.

Penelitian ini juga memperoleh data mengenai perilaku dosen dalam melakukan bimbingan mahasiswa, di mana sebagian besar dosen membimbing sebanyak 2 kali dalam sebulan, dengan nilai minimal sebanyak 1 kali dan maksimal 6 kali dalam sebulan. Sebagian besar dosen memberikan bimbingan selama 60 menit, dengan ratarata selama 47 menit. Hanya ada 2 responden (7\%) yang memberikan bimbingan masing-masing selama 15 menit dan 90 menit.

Tabel 6. Distribusi dosen pembimbing menurut hambatan dalam proses bimbingan KTI

\begin{tabular}{lcc}
\multicolumn{1}{c}{ Hambatan } & $\mathbf{n}(\mathbf{n}=\mathbf{2 9 )}$ & $\mathbf{\%}$ \\
\hline Waktu pembimbing tidak sesuai dengan mahasiswa & 9 & 31,0 \\
Mahasiswa mengalami keterbatas an waktu dan jadwal yang padat & 7 & 24,1 \\
Mahasiswa malas & 5 & 17,2 \\
Mahasiswa pasif & 4 & 13,8 \\
Mahasiswa baru rajin pada saat akhir & 4 & 13,8 \\
Mahasiswa tidak mengikuti apa yang disarankan & 3 & 10,3 \\
Kuliah tentang metpen diberikan saat awal, jadi mahasiswa sudah lupa & 1 & 3,4 \\
Jarak antar pertemuan terlalu lama & 1 & 3,4 \\
Mahasiswa tidak baca literatur & 1 & 3,4 \\
Terpaku pada 1 topik yang sulit dilakukan & 1 & 3,4 \\
Struktur penulisan masih belum nyambung & 1 & 3,4 \\
\hline
\end{tabular}


Penelitian ini juga mendapatkan hambatan lain yang dihadapi dosen dalam proses bimbingan KTI yaitu ketidaksesuaian waktu antara dosen dan mahasiswa (31\%), terbatasnya waktu mahasiswa (24\%), mahasiswa yang malas $(17,2 \%)$ dan pasif $(13,8 \%)$, mahasiswa baru datang di saat terakhir $(13,8 \%)$ dan mahasiswa tidak mengikuti saran dosen pembimbing (10,3\%).

\section{Persepsi Dosen mengenai Kualitas Karya Tulis Ilmiah}

Jumlah dosen yang mengatakan kualitas KTI tinggi dan rendah adalah sama yaitu 50\%, dengan nilai skor ratarata $(29,68)$. Hanya 1 dosen yang memberikan skor 18 dan 1 dosen memberikan skor 21 .

Tabel 7. Distribusi dosen pembimbing menurut kategori kualitas KTI

\begin{tabular}{cccl} 
Kualitas KTI & $\mathbf{n}=\mathbf{2 8 ^ { * }}$ & $\%$ & Ukuran Deskriptif \\
\hline Tinggi & 14 & 50,0 & Mcan $=29,68$ \\
Rendah & 14 & 50,0 & Median $=28,5^{* *}$ \\
& & & Modus $=26$ \\
& & & Max $=40$ \\
& & & Min=18 \\
\hline
\end{tabular}

*1 responden tidak dapat ikut di skor karena jawaban tidak lengkap

${ }^{*}$ Cut off point
Sebagian besar dosen yang memberikan nilai cukup untuk masing-masing bagian dari KTI (41\%-62\%), dan bagian yang dinilai kurang seperti kualitas pencarian dan pengembangan ide $(27,6 \%)$, kualitas kerangka konsep (27,6\%), kesinambungan antar alinea (27,6\%), pembahasan (25\%), kesimpulan dan saran $(20,7 \%)$ dan penggunaan bahasa asing $(20,7 \%)$ (lampiran 2$)$.

\section{Analisa Bivariat}

Penelitian ini mendapatkan hasil yang tidak bermakna untuk sebagian besar variabel, kecuali untuk sikap dosen $(p=0,04)$ dan pendidikan magister $(p=0,02)$. Tabel 8 juga menunjukkan bahwa dosen yang berumur 45 tahun ke bawah (53\% vs $47 \%$ ), mengajar 10 tahun ke bawah (64\% vs $34 \%)$, berjabatan akademik lektor ke bawah ( $53 \%$ vs $47 \%$ ), berpendidikan master ( $69 \%$ vs $31 \%$ ), mempunyai publikasi dalam 3 tahun tahun terakhir (40\% vs $60 \%$ ), melakukan penelitian lebih dari 1 buah dalam 3 tahun terakhir ( $56 \%$ vs $44 \%$ ), bersikap tidak positif ( $78 \%$ vs $22 \%)$, membimbing 2 kali atau lebih (57\% vs 43\%), lama bimbingan kurang dari 45 menit (67\% vs 33\%), lebih banyak menyatakan bahwa kualitas KTI yang mereka bimbing masih rendah.

Tabel 8. Hasil analisa bivariat

\begin{tabular}{lcccc} 
& \multicolumn{4}{c}{ Kategori Kualitas KTI } \\
Karakteristik, Pengetahuan dan Sikap Dosen & $\begin{array}{c}\text { Tinggi } \\
(\mathbf{n}=\mathbf{1 4})\end{array}$ & $\begin{array}{c}\text { Rendah } \\
(\mathbf{n}=\mathbf{1 4})\end{array}$ & $\begin{array}{c}\text { Total } \\
(\mathbf{n}=\mathbf{2 8})\end{array}$ & p value \\
& $\mathbf{n}(\mathbf{\%})$ & $\mathbf{n}(\%)$ & $\mathbf{n}(\mathbf{\%})$ & \\
\hline Umur 45 tahun ke bawah & $7(46,7)$ & $8(53,3)$ & $15(100)$ & 0,705 \\
Lama Mcngajar 1-10 tahun & $4(36,4)$ & $7(63,6)$ & $11(100)$ & 0,246 \\
Jahatan Akademik Asisten Ahli dan Lektor & $7(46,7)$ & $8(53,3)$ & $15(100)$ & 0,705 \\
Program Studi Klinik & $7(50,0)$ & $7(50,0)$ & $14(100)$ & 1,00 \\
Pendidikan Magister & $5(31,3)$ & $11(68,8)$ & $16(100)$ & 0,022 \\
Mempunyai Publikasi dalam 3 tahun terakhir & $6(40)$ & $9(60,0)$ & $15(100)$ & 0,256 \\
Penelitian dalam 3 tahun terakhir berjumlah & & & & \\
lebih dari 1 buah & $7(43 ., 7)$ & $9(56,2)$ & $16(100)$ & 0,445 \\
Pengetahuan Dosen Tinggi & $8(50,0)$ & $8(50,0)$ & $16(100)$ & 1,00 \\
Sikap Dosen Tidak Positif & $2(22,2)$ & $7(77,8)$ & $9(100)$ & 0,04 \\
Jumlah Bimbingan 2 kali atau lebih & $10(43,5)$ & $13(56,5)$ & $23(100)$ & 0,139 \\
Lama Tiap Kali Bimbingan kurang dari 45 menit & $3(33,3)$ & $6(66,7)$ & $9(100)$ & 0,23 \\
\hline
\end{tabular}


Dalam penelitian ini, didapatkan adanya hubungan antara pendidikan magister terhadap persepsi dosen mengenai kualitas KTI mahasiswa yang rendah. Hal ini mengindikasikan adanya perbedaan standar yang diharapkan oleh para dosen pembimbing. Perbedaan standar ini dapat disebabkan karena pendidikan magister memberi penekanan kepada penerapan dari pendekatan, metode dan kaidah keilmuan dalam memecahkan permasalahan, melalui penelitian dan pengembangan berdasarkan kaidah ilmiah; sedangkan pendidikan spesialis lebih menekankan kepada penguasaan keahlian dalam aspek-aspek keilmuan profesional spesifik tertentu serta kemampuan mempraktikkan keahlian professional. ${ }^{7}$ Disiplin ilmu dari masing-masing dosen dapat pula mempengaruhi standar dari kualitas KTI mahasiswa yang diharapkan. Beberapa studi menemukan bahwa ketersediaan pedoman yang baik bagi para pembimbing dan training bagi para pembimbing sangat dibutuhkan untuk menyamakan standar ini. ${ }^{8,9}$

Penelitian ini juga menunjukkan hubungan antara sikap dan persepsi dosen mengenai kualitas KTI mahasiswa. Dosen yang memiliki sikap positif lebih banyak yang memberikan nilai tinggi terhadap KTI $(63,2 \%)$ dibandingkan dengan dosen yang mempunyai sikap tidak positif (22,2\%). Lampiran 1 menunjukkan beberapa sikap tidak positif yang kurang menunjang kualitas KTI, seperti sikap tidak tahu/ragu-ragu dan tidak setuju untuk membimbing mahasiswa dalam pengembangan kerangka teori dan kerangka konsep (20,6\%), pemilihan metode penelitian $(13,7 \%)$, pemberian bimbingan minimal sebanyak 4 kali (14\%), pencarian literatur (28\%) dan pengkoreksian KTI (hanya mengoreksi bagian yang dianggap penting saja) (24.1\%). Lampiran 1 juga menunjukkan beberapa sikap tidak positif lainnya seperti sikap harus ikut campur dalam penelitian dan ikut campur pencarian literatur. Dalam pedoman KTI FKUAJ salah satu tujuan dari pembuatan KTI adalah untuk mengasah keterampilan kerja mandiri mahasiswa mulai dari identifikasi masalah sampai penyampaian hasil penelitiannya. ${ }^{7}$ Hasil penelitian ini mengindikasikan ketidak jelasan sejauh mana tugas dosen pembimbing untuk menjamin tercapainya tujuan tersebut. Tampaknya pedoman yang lebih detil bagi para dosen pembimbing, yang disosialisasikan dengan lebih baik, sangat diperlukan. $^{8,9}$
Bervariasinya sikap dosen dalam membimbing mahasiswa juga mengindikasikan bahwa kemampuan mahasiswa dalam mengerjakan KTI sangat bervariasi. Sebuah studi di Nepal menemukan bahwa sikap dan pengetahuan mahasiswa terhadap ilmu pengetahuan dan metodologi ilmiah lebih rendah pada mahasiswa semester pertama. Akan tetapi nilai yang rendah juga didapatkan pada mahasiswa semester ketiga dan keempat. ${ }^{10} \mathrm{Hal}$ ini menunjukkan bahwa perlu adanya kegiatan yang terkait dengan materi metodologi penelitian dan evidence-based medicine di setiap semester yang dilalui mahasiswa. Di Atma Jaya, pada tahun 2006 sampai dengan 2011, metodologi penelitian dan evidence based medicine diberikan pada semester tiga (pada blok metodologi penelitian), sedangkan proses pembuatan karya tulis ilmiah dilakukan pada semester 4 ke atas. Hal ini mengindikasikan bahwa perlu adanya integrasi dari metodologi penelitian ke dalam blok-blok organ setelah blok metodologi penelitian, sehingga kemampuan mahasiswa dalam membuat karya tulis ilmiah menjadi lebih merata. Hal ini senada dengan sebuah studi di Malaysia yang menemukan bahwa menulis ilmiah untuk berbagai topik penting bagi kesuksesan mahasiswa dan meningkatkan ekspresi dari penulisan itu sendiri. ${ }^{5}$ Beberapa studi menemukan bahwa mahasiswa perlu dijelaskan secara eksplisit mengenai kriteria penilaian dan bagaimana cara mencapai hasil penilaian yang baik dalam tulisan mereka. ${ }^{11,12}$ Mahasiswa juga perlu diberikan kuliah mengenai tulisan-tulisan ilmiah dalam berbagai topik yang mereka jalani. Salah satu yang direkomendasikan oleh studi ini adalah dengan menyediakan tulisan ilmiah sebagai model untuk analisis dan penilaian, sesuai topik yang mereka jalani. ${ }^{12}$ Selain itu ada beberapa cara untuk meningkatkan kemandirian mahasiswa seperti keharusan membuat cover letter setiap kali memasukkan draft ke dosen pembimbing. Dalam cover letter tersebut mahasiswa harus membuat pernyataan atau pertanyaan spesifik mengenai hal yang mereka inginkan untuk di review oleh dosen pembimbing. Dalam cover letter juga mereka harus menyatakan bagaimana mahasiswa memperbaiki draft KTI berdasarkan masukan dari para dosen pembimbing (bila lebih dari satu) dan pertimbangan apa yang mendasari perbaikan tersebut. Kegiatan ini dikatakan dapat membuat mahasiswa menjadi lebih aktif 
dan mandiri karena harus memutuskan tidak sematamata karena saran dosen pembimbing, tetapi juga karena mereka harus memberikan alasannya. ${ }^{13}$ Literatur lain mengungkapkan selain memberikan pengajaran dan skill lab ataupun praktikum mengenai metode penelitian, cara mencari informasi, statistik, intepretasi artikel ilmiah dan keterampilan penggunaan software yang berkaitan dengan penelitian, penting juga untuk mengajarkan kepada mahasiswa mengenai proses publikasi ilmiah termasuk proses peer review sehingga mahasiswa dapat mengetahui poin-poin penilaian suatu artikel yang layak dipublikasikan. ${ }^{8}$ Sebuah studi di Kroasia mengungkapkan bahwa pengetahuan, sikap dan perilaku mahasiswa terhadap metode dan penulisan ilmiah berhubungan dengan nilai dan rangking pada saat tes masuk. ${ }^{14} \mathrm{Akan}$ tetapi dalam penelitian ini, kami belum menghubungkan persepsi dosen tentang kualitas KTI yang rendah dengan nilai tes masuk mahasiswa yang dibimbing.

Penelitian ini juga mengindikasikan bahwa sikap dan perilaku mahasiswa sendiri juga menentukan kualitas KTI yang baik. Tabel 6 juga menunjukkan bahwa beberapa hambatan yang dirasakan oleh dosen pembimbing dalam memberikan bimbingan KTI adalah mahasiswa mempunyai keterbatasan waktu dan jadwal yang padat $(24,1 \%)$, mahasiswa malas $(17,2 \%)$ dan pasif $(13,8 \%)$. Selain itu kebiasaan mahasiswa yang baru datang pada saat akhir $(13,8 \%)$ membuat bimbingan KTI tidak dapat berlangsung secara optimal. Beberapa literatur mengungkapkan hasil yang sama di mana mahasiswa menunjukkan sikap pasif dalam proses pembuatan KTI. Hal ini salah satunya karena persepsi mahasiswa sebagai pemula dan dosen pembimbing sebagai orang yang lebih berpengalaman, sehingga para mahasiswa cenderung menganggap bahwa dosen pembimbing akan memberitahu semua hal yang perlu dilakukan untuk menghasilkan KTI yang baik. ${ }^{12}$ Oleh karena itu perlu dilakukan pemberitahuan kepada mahasiswa mengenai tujuan KTI dan sikap serta perilaku mahasiswa yang dibutuhkan untuk mencapai tujuan tersebut. Literatur lain juga menyebutkan bahwa pada umumnya mahasiswa bersikap pasif bila topik yang diteliti bukan topik yang paling mereka minati. Oleh karena itu pembagian dosen pembimbing utama harus disesuaikan dengan topik yang diinginkan oleh mahasiswa. ${ }^{15}$
Penelitian ini juga mendapatkan hasil yang tidak bermakna antara karakteristik (jenis kelamin, umur dosen, lama dosen mengajar, jabatan akademik dosen) dan pengetahuan, dengan persepsinya terhadap kualitas KTI. Secara deskriptif dosen yang lebih muda (kurang dari 45 tahun) dengan jabatan akademik asisten ahli dan lektor, serta mengajar kurang dari 10 tahun lebih cenderung menyatakan kualitas KTI yang rendah. Hal ini mengindikasikan perlunya dilakukan evaluasi terhadap indikator lainnya seperti pedoman KTI itu sendiri, analisis hasil KTI oleh kelompok reviewer yang terpilih secara obyektif, pengetahuan, sikap dan perilaku mahasiswa dan juga terhadap proses kebijakan yang ada di fakultas, bahkan sampai kepada mata kuliah yang berkaitan dengan pembuatan KTI mahasiswa. ${ }^{10-15}$

Penelitian ini juga menunjukkan ketidak konsistenan antara pengetahuan, sikap dan perilaku dosen pembimbing. Oleh karena itu selain perlu dilakukan evaluasi pada indikator lainnya, peningkatan kejelasantugas dosen dan motivasi para dosen agar mau membimbing mahasiswa sesuai dengan tujuan yang akan dicapaijuga perlu dilakukan.

\section{KESIMPULAN}

Secara umum persepsi dosen terhadap kualitas KTI masih rendah, dan hanya berhubungan dengan pendidikan magister dan sikap dosen. Oleh karena itu perlu dilakukan evaluasi terhadap indikator lainnya seperti review terhadap pedoman KTI itu sendiri, analisis hasil KTI oleh kelompok reviewer yang terpilih secara obyektif, pengetahuan, sikap dan perilaku mahasiswa, kebijakan dan teknis pelaksanaan yang ada di fakultas, bahkan mata kuliah yang berkaitan dengan pembuatan KTI mahasiswa.

\section{DAFTAR PUSTAKA}

1. Steps of the scientific method. Science buddies [Internet]. 2010.[cited 2010 July 10]. Available from:http:// www.sciencebuddies.org/science-fair-projects/ project_scientific_method.shtml.

2. HN Kumar, S Jayaram, Ganesh S Kumar, J Vinita, S Rohit, K Shusruth, Nitin, Akhilesh. Perception, practices towards research and predictors of research career among UG medical students from coastal South India: a cross sectional study. Indian J Community Med. 2009; 34(4):306-9. 
3. R Travelyan, J Cook, M Fisher. Skill series: scientific writing \& publishing results. Tropical biology association. Cambridge 2007. [cited 2011 Aug 18]. Available from:http://www.tropical-biology. org/ admin/documents/pdf_files/Skills_series/ Scientific\%20Writing_FINAL.pdf.

4. LD Stadler. Scientific writing skills for MPA students. 2002. [cited 2010 July 10]. Available from: http:// academic.sun.ac.za/taalsentrum/PowerPoint / index_eng2.htm [10

5. Fung Lan Yong. Attitudes toward academic writing of foundation students at an Australian-based university in Sarawak. European journal of social sciences. 2010; 13 (3): 471-7.

6. Pedoman prosedur penyusunan karya tulis ilmiah. Fakultas Kedokteran Universitas Katolik Indonesia Atma Jaya; 2007.

7. Standar isi pendidikan tinggi. Badan standar nasional pendidikan. Jakarta 2010. [cited 2013 Januari 24]. Available from: http://ppp.ugm.ac.id/wp-content/ uploads/standarisi-pt-bsnp.pdf.

8. Pentti Nieminen, Kirsi Sipila, Hanna-Mari Takkinen, Marjo Renko, Leila Risteli. Medical theses as part of the scientific training in basic medical and dental education: experiences from finland. BMC Medical Education. 2007;7(51). [cited 2013 January 24]. Available from: http://www.biomedcentral.com/ $1472-6920 / 7 / 51$.
9. Julie Reynolds, Robin Smith, Cary Moskovitz, Amy Sayle. Biotap: a systematic approach to teaching writing and evaluating undergraduate theses. Bioscience. 2009; 59(10):896-903

10. Atif bin Tareef. Scientific research in Jordanian Higher Education Institutions: an Evaluation of Status and Obstacles. Journal of Instructional Psychology. 2009; 36(2):158-168.

11. Shankar PR, Dubey AK, Upadhyay DK, Subish P, Mishra P. Science Attitudes and Knowledge among preclinical medical students in Pokhara, Nepal. Coll. Antropol. 2007;30(3):667-673

12. Shaw AEO. Lecturer and student perceptions of an academic writing task. Thesis for Master of Education (english second language). Rhodes University. January 1996.

13. Loke KK, Bartlett B. What distinguishes a distinction? Perceptions of quality academic performance and strategies for achieving it. In: Reimagining practice: researching change. Griffith University. 2007.

14. Vodopivec I, Vujaklija A, Hrabak M, Lukiæ IK, Marušiæ A, Marušiæ M. Knowledge about and Attitude towards science of first year medical students. Croat Med J. 2002; 43(1): 58-62.

15. Burgoyne LN, O’Flynn S, Boylan GB. Undergraduate medical research: the student perspective. Med Educ Online. 2010;15: 10.3402/meo.v15i0.5212. 
Lampiran 1. Tabel Distribusi Sikap Dosen Pembimbing

\begin{tabular}{|c|c|c|c|c|}
\hline Sikap & $\begin{array}{l}\text { Setuju } \\
\mathbf{n}(\%)\end{array}$ & $\begin{array}{c}\text { Ragu-ragu/ } \\
\text { tidak tahu } \\
\text { n (\%) }\end{array}$ & $\begin{array}{c}\text { Tidak } \\
\text { setuju } \\
\text { n (\%) }\end{array}$ & $\begin{array}{l}\text { Total } \\
\text { n (\%) }\end{array}$ \\
\hline $\begin{array}{l}\text { Tugas dosen adalah membantu mahasiswa memilih topik } \\
\text { sesuai minat mahasiswa. }{ }^{*}\end{array}$ & $\begin{array}{c}29 \\
(100 \%)\end{array}$ & 0 & 0 & $\begin{array}{c}29 \\
(100 \%)\end{array}$ \\
\hline $\begin{array}{l}\text { Tugas dosen ada lah membantu mahasiswa dalam membuat } \\
\text { kerangka teori dan kerangka konsep. }\end{array}$ & $\begin{array}{c}23 \\
(79,3 \%)\end{array}$ & $1(3,4 \%)$ & $5(17,2 \%)$ & $\begin{array}{c}29 \\
(100 \%)\end{array}$ \\
\hline $\begin{array}{l}\text { Tugas dosen adalah membantu mahasiswa memilih metode } \\
\text { penelitian.* }\end{array}$ & $\begin{array}{c}25 \\
(86,2 \%)\end{array}$ & $1(3,4 \%)$ & $3(10,3 \%)$ & $\begin{array}{c}29 \\
(100 \%)\end{array}$ \\
\hline $\begin{array}{l}\text { Tugas dosen adalah membantu mahasi swa dalam kelancaran } \\
\text { pelaksanaan penelitian dan penulisan proposal. * }\end{array}$ & $\begin{array}{c}27 \\
(93,1 \%)\end{array}$ & $2(6,9 \%)$ & 0 & $\begin{array}{c}29 \\
(100 \%)\end{array}$ \\
\hline $\begin{array}{l}\text { Setiap dosen pembimbing harus mempunyai buku pedoman } \\
\text { prosedur penyusunan KTI.* }\end{array}$ & $\begin{array}{c}29 \\
(100 \%)\end{array}$ & 0 & 0 & $\begin{array}{c}29 \\
(100 \%)\end{array}$ \\
\hline $\begin{array}{l}\text { Setiap dosen pembimbing harus membaca dan mengetahui isi } \\
\text { pedoman penyusunan KTI.* }\end{array}$ & $\begin{array}{c}29 \\
(100 \%)\end{array}$ & 0 & 0 & $\begin{array}{c}29 \\
(100 \%)\end{array}$ \\
\hline $\begin{array}{l}\text { Setiap dosen harus memberikan bimbingan minimal empat } \\
\text { kali sebelum seminar proposal* }\end{array}$ & $\begin{array}{c}25 \\
(86,2 \%)\end{array}$ & $2(6,9 \%)$ & $2(6,9 \%)$ & $\begin{array}{c}29 \\
(100 \%)\end{array}$ \\
\hline $\begin{array}{l}\text { Dosen pembimbing harus ikut campur dalam pelaksanaan } \\
\text { penelitian }^{* *}\end{array}$ & $\begin{array}{c}9 \\
(31,0 \%)\end{array}$ & $3(10,3 \%)$ & $17(58,6 \%)$ & $\begin{array}{c}29 \\
(100 \%)\end{array}$ \\
\hline $\begin{array}{l}\text { Dosen pembimbing hanya memberi petunjuk dalam } \\
\text { pencarian literatur. }{ }^{*}\end{array}$ & $\begin{array}{c}23 \\
(86,2 \%)\end{array}$ & $1(3,4 \%)$ & $3(10,3 \%)$ & $\begin{array}{c}29 \\
(100 \%)\end{array}$ \\
\hline Dosen pembimbing ikut campur dalam mencari literatur. ** & $\begin{array}{c}7 \\
(24,1 \%)\end{array}$ & $7(24,1 \%)$ & $15(51,7 \%)$ & $\begin{array}{c}29 \\
(100 \%)\end{array}$ \\
\hline $\begin{array}{l}\text { Dosen pembimbing tidak ikut campur sama sekali dalam } \\
\text { pencarian literatur. }{ }^{* *}\end{array}$ & $\begin{array}{c}4 \\
(13,8 \%)\end{array}$ & $4(13,8 \%)$ & $21(74,4 \%)$ & $\begin{array}{c}29 \\
(100 \%)\end{array}$ \\
\hline $\begin{array}{l}\text { Dosen pembimbing hanya mengoreksi kesalahan -kesalahan } \\
\text { penting pada KTI mahasiswa.*** }\end{array}$ & $\begin{array}{c}7 \\
(24,1 \%)\end{array}$ & 0 & $22(75,9 \%)$ & $\begin{array}{c}29 \\
(100 \%)\end{array}$ \\
\hline $\begin{array}{l}\text { Dosen pembimbing mengoreksi seluruh kesalahan yang ada } \\
\text { dalam KTI mahasiswa.* }\end{array}$ & $\begin{array}{c}22 \\
(75,9 \%)\end{array}$ & $2(6,9 \%)$ & $5(17,2 \%)$ & $\begin{array}{c}29 \\
(100 \%)\end{array}$ \\
\hline $\begin{array}{l}\text { Sumber informasi yang digunakan untuk KTI adalah } 5 \text { tahun } \\
\text { terakhir.* }\end{array}$ & $\begin{array}{c}26 \\
(89,7 \%)\end{array}$ & $2(6,9 \%)$ & $1(3,4 \%)$ & $\begin{array}{c}29 \\
(100 \%)\end{array}$ \\
\hline Sikap mahasiswa dinilai pada saat ujian presentasi KTI. * & $\begin{array}{c}28 \\
(96,6 \%)\end{array}$ & 0 & $1(3,4 \%)$ & $\begin{array}{c}29 \\
(100 \%)\end{array}$ \\
\hline $\begin{array}{l}\text { Cara mahasiswa menyajikan KTI secara lisan dinilai saat ujian } \\
\text { presentasi KTI.* }\end{array}$ & $\begin{array}{c}29 \\
(100 \%)\end{array}$ & 0 & 0 & $\begin{array}{c}29 \\
(100 \%)\end{array}$ \\
\hline $\begin{array}{l}\text { Kemampuan mahasiswa untuk menjawab pertanyaan yang } \\
\text { diajukan penguji dinilai saat ujian presentasi KTI. }{ }^{*}\end{array}$ & $\begin{array}{c}29 \\
(100 \%)\end{array}$ & 0 & 0 & $\begin{array}{c}29 \\
(100 \%)\end{array}$ \\
\hline $\begin{array}{l}\text { Sistematika penulisan proposal tidak dinilai saat ujian } \\
\text { presentasi KTI.** }\end{array}$ & $\begin{array}{c}9 \\
(31,0 \%)\end{array}$ & $3(10,3 \%)$ & $15(58,6 \%)$ & $\begin{array}{c}29 \\
(100 \%)\end{array}$ \\
\hline
\end{tabular}

* Sikap positif bila setuju

** Sikap positif bila tidak setuju 
Lampiran 2. Persepsi Dosen Pembimbing Terhadap Komponen KTI yang Kurang Baik

\section{Komponen KTI yang Kurang Baik}

$\mathrm{n}=29$

$\%$

Pencarian dan Pengembangan Ide

Kerangka Konsep

$8 \quad 27,6$

Kesinambungan Antar Alinea

$8 \quad 27,6$

Pembahasan *

$8 \quad 27,6$

Kesimpulan dan Saran

$7 \quad 25,0$

Susunan Bahasa dan Penggunaan Bahasa Asing

$6 \quad 20,7$

Pendahuluan

$6 \quad 20,7$

Definisi Operasional

$5 \quad 17,2$

Abstrak

$4 \quad 13,8$

Judul Proposal

$4 \quad 13,8$

Metodologi Penelitian

10,3

Tinjauan Pustaka

10,3

Hasil Penelitian *

$2 \quad 6,9$

${ }^{*} \mathrm{n}=28$ karena 1 orang tidak menjawab 